\title{
オープンロールにおけるゴムの熱的挙動
}

隠 塚 裕 $之^{1} \cdot$ 藤 道 治 $^{2}$

\section{Mill Behavior of Rubber on Two Roll Mill with Temperature}

Hiroyuki ONTSUKA ${ }^{1}$ and Michiharu $\mathrm{TOH}^{2}\left({ }^{1}\right.$ Chemicals Evaluation and Research Institute, Nagoya, Japan, 1, 4Chome, Orito-cho, Showa-ku ,Nagoya-shi, Aichi 466-0858, Japan, ${ }^{2} \mathrm{R} \&$ D Department, Kurume Research Park Co., Ltd., 1-1 Hyakunenkouen, Kurume-shi, Fukuoka 839-0864, Japan)

The mixing of unvulcanized compounds and vulcanizing agents is performed on two roll mills at present. It was known that the mixing between the rubber and ingredients is conducted only at the nip on the two roll mill. So the size and temperature of bank at the nip, and the clearance of nip are very important.

It was found that when the roll temperature was varied, four regions of mill behavior were observed. In region 1 the highly elastic rubber will scarcely move into the mil nip at room temperature. In region 2 a good elastic rubber band is obtained on one of rolls. In region 3 the elastomer crumbles and bagging or crumbs occur. In region 4 a melt fluid coats on one of rolls at high roll temperature.

In this paper, mill behavior of rubber on two roll mills with the variation of temperature was expressed.

(Received on February 25, 2015)

Key Words : Two Roll Mill, Roll Temperature, Rubber Temperature, Bank Temperature, Heat Transfer

\section{1. は じ め に}

オープンロールは，1833年にChaffeeによって発明され て以来改良されて今日に至っている。しかし，オープンロ ールにおけるゴムの熱的挙動に関する報告は少なく，ゴム 練り作業や混合作業の中で説明されているに過ぎない。こ こでは，これまでに報告されている中からオープンロール でのゴム練りと温度との関わりなどについて紹介する。

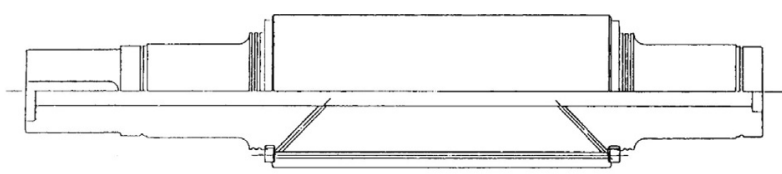

ドリルド・ロール

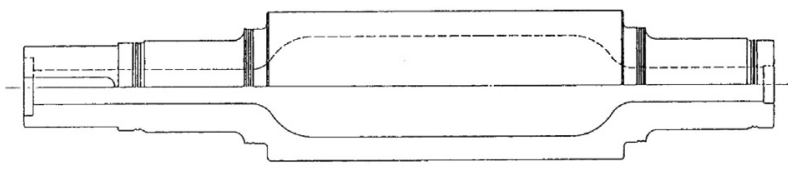

ボアード・ロール

図1 ドリルド・ロールとボアード・ロール

\section{2. オープンロール内の伝熱流路について}

オープンロールには，内部が図1のような中空で厚い肉 厚を通して伝熱を行うボアード・ロール（Bored Roll）と， 図1のようなロール表面近傍まで伝熱流路が設けられ表面 温度が比較的均一なドリルド・ロール（Drilled Roll）が ある1). Banburyが密閉型のバンバリーミキサーを発明し

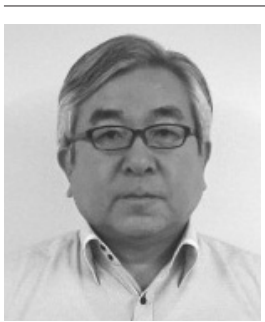

隠塚 裕之; (一財) 化学物質評価研究機構名古屋 事業所（干466-0858 名古屋市昭和区折戸町 4-1). 1983 年福岡大学大学院理学研究科化学専攻修了, 同年（財）化学品検査協会（現（一財）化学物質評 価研究機構）に入社, 現在に至る.1991年〜 ISO/TC45/SC2物理試験方法分科会にて JIS， ISO 規格作成に従事，2002年～2004年，2011年〜日本 ゴム協会東海支部副支部長. 専門は，高分子材料の 配合設計，物理試験.

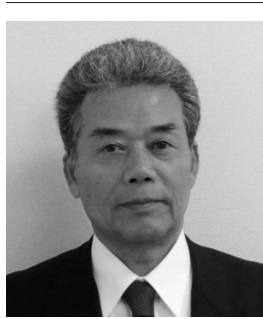

藤 道治；（株）久留米リサーチ・パーク（８８39 0864 久留米市百年公園 1 番 1 号) 研究開発部人材 育成コーディネータ, 工博. 1966年九州大学大学院 工学研究科化学機械工学専攻修了, 1971年国立久留 米工業高等専門学校工業化学科講師，2006年停年退 職，名誉教授，2006年〜人材育成コーディネータ, 化学工学会 粒子・流体プロセス部会ミキシング技 術分科会評議員，2000年～2002年日本ゴム協会九州 支部長，編集委員，ゴム練り研究分科会主査．専門 は, 化学工学（掻き取り攪拌伝熱, 混練, 粉砕). 
た 1916 年の 1 年前，今から 100 年前の 1915 年にPearson は 著書Rubber Machinery ${ }^{2)}$ において当時主流のゴム練り機 であるオープンロールに対して，生産量を二倍にするため に回転数やロール面長を従来機の二倍ほどにしたこと，加 温やゴム練り時の発熱によるスコーチを防ぐために蒸気や 冷却水を流す様々な伝熱方式を持つオープンロールについ て説明している.

ドリルド・ロールとして，ロール表面近傍に軸方向（長 手方向）に8本の直線的な流路を設けたCowen-Bragg Cooling Roll と, ロール表面近傍にらせん状の流路を設け たBragg Cooling Roll及びそれらの改良型のBrag BuiltUp Rollを紹介している。また，ボアード・ロールとして， 中空内壁にリブを設けリブ間に8本の多孔伝熱管を配置し たBrewster Cooling Roll とその改良型, 中空部円筒を6枚 のパーティションで分割して長手方向に仕切った流路を設 けたNorris Cooling Rollを紹介している。

\section{3. ロール上のゴム温度変化}

\section{1 ゴムとロールなどとの伝熱}

1930 年の護謨にYoung の報告 ${ }^{3)}$ が石黒により翻訳され て「護謨混和機と混和法」として揭載されている ${ }^{4)}$. 二本 ロール混和機（以後オープンロールと呼ぶ）は，密閉式混 和機（以後インターナルミキサーと呼ぶ）よりも平均温度 は低いが温度分布があるとして図 2 に示すような温度変化 などが示されている。目はニップ（ロール最小間隙）Nで 7/32 インチで $5.5 \mathrm{~mm}$ ，カレンダーシートはバンド厚みで 12/32 インチで $9.5 \mathrm{~mm}$ である。前ロール上のゴム温度は, $\mathrm{N}$ のニップ部で $105{ }^{\circ} \mathrm{C}$ ，ニップ通過後出口部 1 で $86{ }^{\circ} \mathrm{C}$ ，そ れ以降はロール下端部 2 で $82^{\circ} \mathrm{C}$, ロール水平部 3 で $79^{\circ} \mathrm{C}$, ロール上端部 4 で $76{ }^{\circ} \mathrm{C}$ である。空気中での前ロール $90^{\circ}$

（2）～270（4）においては，ゴム温度は放熱により $90^{\circ}$ 毎に $3{ }^{\circ} \mathrm{C}$ 低下しているが，これに対してロール上端部 4 か ら $\mathrm{N}$ までは約 10 倍 $30^{\circ} \mathrm{C}$ の温度上昇があり， $\mathrm{N}$ から 1 まで 約 $20{ }^{\circ} \mathrm{C}$ 温度が低下している。

ニップに至るまでの温度上昇は回転するバンク（たまり ゴム）内の配合剤とゴムとの混合による発熱，ニップに至 る過程でゴムバンドとバンクとの摩擦による発熱及びゴム が高速で伸長されることによる発熱によると考えられる.

ニップにおける限界温度 (critical temperature:スコー チがおこる上限温度）が，後ロールの冷却により低く保た れていると述べられ，スコーチが起こるゴム温度より低く していたのではないかと考えられる。この場合，バンクと 接触しながらニップを通り抜けた後ロールは，ロール表面 から空気への対流伝熱（heat convection）と放射伝熱 (heat radiation）により，また，ロール表面から中空内壁 面へは先ず熱伝導（heat conduction）により，次に内壁 面から冷却水への対流伝熱で熱が移動し，常に冷却されて
いると考える.

前ロール上のバンドゴムは，ロール内の冷却水により冷 却され，また，対流と放射により冷却されていると述べら れている。ロールと接しているバンドゴムの熱は，ロール の表面から伝導により中空内壁面に伝わり，内壁面から冷 却水に対流伝熱により移動する。また，回転しているバン ドゴム表面からの冷却は, 空気と接触しているので空気と の対流伝熱と空気を介しての放射伝熱によるものであると 考元る。

原著には, 図 2 の練り条件などは記述されていないが, 図 2 の付図に 5 種類のオープンロールの諸元などが示され ている。図 2 のロールは直径 36 か 40 インチ，ロール面長 84 インチの非常に大きなロールであり，また，後ロール の回転数は毎分 15 回転前後, 回転比 2 程度と推測される。 例えば，40 インチの後ロール表面速度は 16 回転とした場 合毎分 $51 \mathrm{~m}(0.85 \mathrm{~m} / \mathrm{s})$ となる。練りと配合剂の投入速度, 投入量などについて問題とされているが，スコーチ温度か らゴムは天然ゴムと推測される。

\section{2 ニップにおける限界温度}

ゴムを混和するオープンロールとインターナルミキサー の最も明確な差異は，オープンロールではゴムがニップの 間で限界温度下で通過するのに対してインターナルミキサ 一ではかかる憂いがないと述べている。 また，以下のこと が述ベられている.オープンロールではニップの間のゴム 層だけが配合剤と接触するにすぎないが，インターナルミ キサーではこの接触が全体的にある，オープンロールでは 混合時のゴム平均温度は $90 \sim 95{ }^{\circ} \mathrm{C}$ であるが，インターナ ルミキサーにあってはゴム平均温度は一般に $100 \sim 105{ }^{\circ} \mathrm{C}$

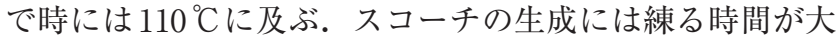
きな因子であることを忘れてはならない.インターナルミ

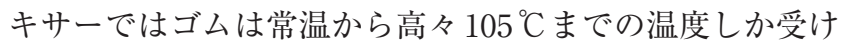

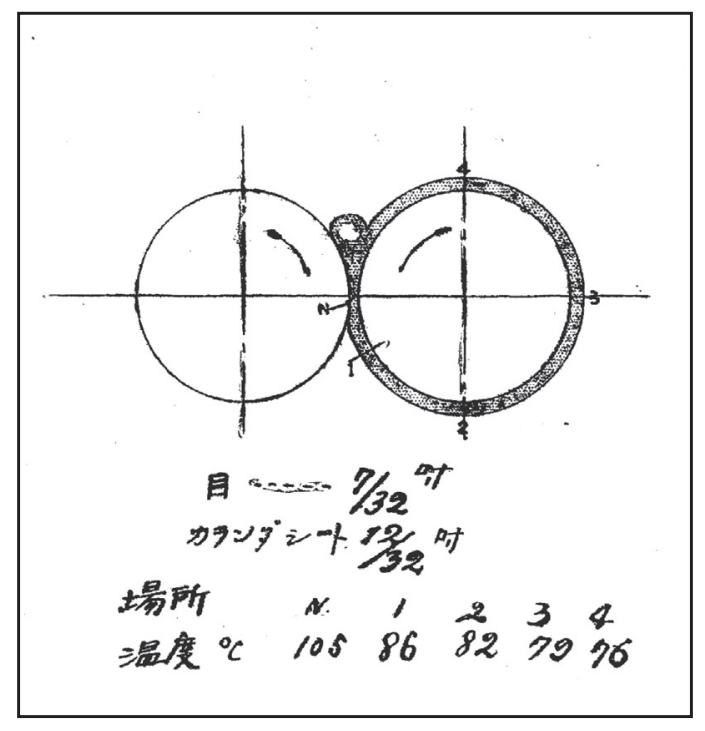

図2 二本ロール混和機におけるゴムの温度分布 
ておらず，しかも 6〜7分で練りが終わってしまう。オー プンロールの場合には平均のゴム温度は $95^{\circ} \mathrm{C}$ までである が，練りに 35 分以上を要して限界温度の $120^{\circ} \mathrm{C}$ 至るニッ プのところを 500 回以上も通過する．そこで，スコーチの 危険という観点から見ればオープンロールの方にあるよう に思うと述べている。

\section{3 ニップ通過後のゴム温度低下と負圧について}

温度が高いバンクと接触して加熱された冷却用後ロール 表面は，バンクを通りニップから出た時点で表面からゴム が剥がれて空気にさらされる。ニップ通過後に両ロールが 離れた直後の圧力は大気圧よりも下がり負圧が発生し, キ ヤビテーションが起こっているのではないかと考えられ る.このため，前ロール上バンドゴム表面から配合された 低沸点物質が大気中へ揮発し，図 2 の N から出口部 1 の間 でバンドゴム表面温度は $20{ }^{\circ} \mathrm{C}$ 程温度がかなり大きく下が ったと考える，負圧が発生することは，オープンロールで はないが次の報告などから推測される。

Banks ら ${ }^{5)}$, Myers ら 6, 7) は, ニュートン流体であるオ イルを使ってロールコーターのニップにおける流れを詳細 に観察して 4 領域，二次流れを呈すバンク領域，ニップ部 のせん断領域, ニップ後の圧力降下によるキャビテーショ ン領域と両ロールが離れるところのフィラメント領域に分 けている，また，鄭8) は，塗料用ステンレス製 2 本ロール ミル（直径 $16.4 \mathrm{~cm}$ ，ロール面長 $20 \mathrm{~cm}$ ）においてニュー トン流体の重合アマニ油を混練した場合のニップ（間隔 70-780 $\mu \mathrm{m} ）$ での圧力変化を測定している。低速側ロール を固定し, 内部からニップ部ロール表面近くに圧力センサ 一を取り付け，高速側ロールを回転させた場合のニップ部 の圧力変化を測定して，ニップ前後の圧力が正圧から負圧 となることを実測し, 理論的一致することを見出している.

また, Tohらは二次元モデルミキサーのローター, ゴム とボイドの動きをビデオカメラで撮影して図 3 (a) で表 している ${ }^{9)}$ 、ローター前方にボイド（空隙）は無くゴムで 満たされ鎌状領域が形成され，ローター後方はボイド（空 隙）で占められている。 また，ローターチップと槽内壁面 間のクリアランス部から後方ボイド部にシート状ゴムが出 ている.図3（b），(c）はクリアランス部を拡大したもの で，ローターチップ側のゴムはクリアランス部後端ですぐ 剥がれて表面に波立ちが起こり，しかも，槽内壁面からの 剥がれよりも常に先に剥がれが起こっているように見え， 実際のビデオ画像からもそれが観察された。

権藤 ${ }^{10)}$ は, 小型混練機の槽壁に圧力センサーを取付け, ゴム混練り時の槽内壁面圧力を測定し，ローターチップが センサー面を通過した直後に負圧が発生して図 3 (d) の 掻き取羽根前後の圧力変化 ${ }^{11)}$ に類似していると述べてい る.

図3（e）は図2のニップ部を拡大したものである。オー

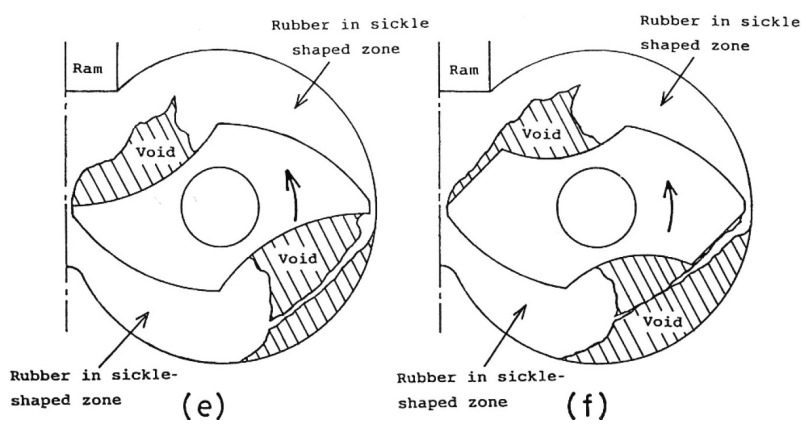

図3(a)（e）ローターと(f)ローターにおけるゴムとボイドの挙動

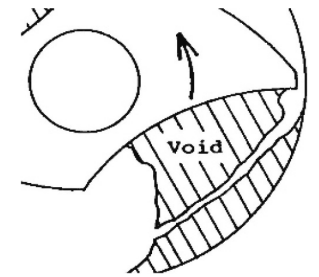

図3(b)（e）ローターのクリア ランス部拡大図
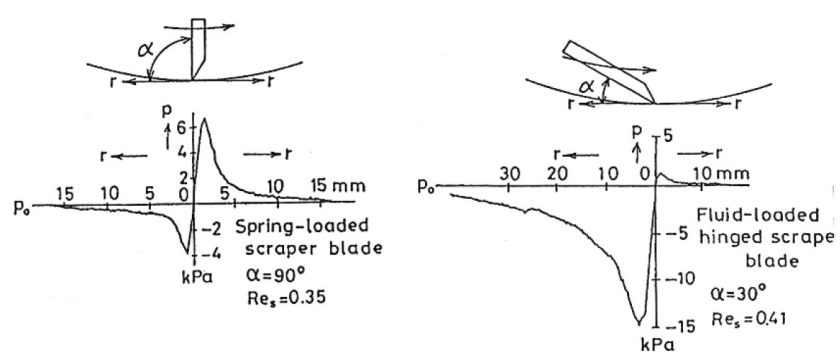

図3（d）搔き取り羽根前後における槽内壁圧力分布

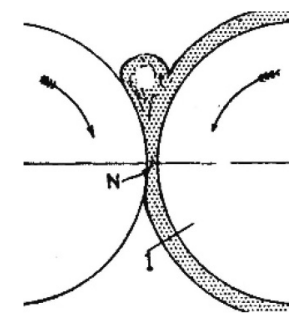

図3(e) ニップ周辺拡大図

プンロールにおいてニップ直後で後ロールが前ロールのバ ンドゴムから剥がれるときには負圧となり，丁度ローター チップ側からゴムが剥がれたように，後ロールからバンド ゴムが剥がれてその表面は波立ち収縮などが起こっている ものと考える。

\section{4. ゴムの混合過程とバンクの生成}

1943年森 ${ }^{12)}$ は混合作業（ゴム練り）において 図 4 に示 すようなゴムの混合状態を示し，混合作業につき注意すべ き点は，一般的に見て，(1）配合諸材料をなるべく短時間 に各部分均等に混加（混合）すること。（2）ゴムを焼けと 


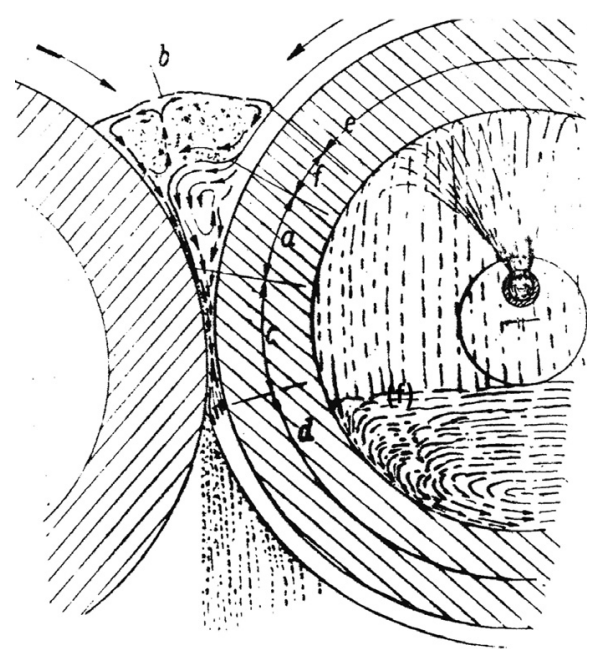

図4 ゴムの混合状態

称する半加硫状態にしないことである，とし，ロール温度， 間隙の調節及びその他の操作が適当でなければ配合薬品は 完全に各部分に分布せず小塊状に固まるとしている．図中 の a，b，c，d，e，fについては説明していない。しかし， Macbeth $^{13)}$ が1935年にゴムの混合過程として同じ図面を 示し，ゴム温度を示していないが，a〜fについて次のよ うに説明していた。

$\mathrm{a}$ ：ゴムの膨らみ（バンク）がニップの方に引き延ばさ

れて早く動き出す区間

$\mathrm{b}$ ：集まった配合剤がaのゴムと同時に後ロールにより 引き込まれる区間

c：ゴムの速度が一番速くなり, 温度上昇が大きくロー ルへ熱が移動する区間

$\mathrm{d} \sim \mathrm{e} ：$ ゴムの温度が徐々に低下する区間

$\mathrm{f}$ ：配合剤のバンクに接してゴム温度が上昇し始める区 間

図4は，この図面を参考にしたものと思われる.

\section{5. ロール温度と練り挙動}

1966年にTokita ら ${ }^{14,15)}$ ，White ${ }^{16)}$ は，3インチオープ ンロールを使ってロール温度を変えた場合の BR，SBRな どの素練りを観察撮影して練り挙動が図 5 に示すように温 度により領域 1 から領域 4 までの 4 つの領域に分けられる ことを見出している．さらに，これらの領域を理論的に解 析している. 回転数は前ロール $16.2 \mathrm{rpm}$, 後ロール 22.7 $\mathrm{rpm}$ でニップを 0.055 インチ $(1.4 \mathrm{~mm})$ としている。領域 1 では，室温でゴムが弾性支配でニップに食い込まない． 領域 2 では，温度が $66 \sim 71{ }^{\circ} \mathrm{C}$ でニップを通ったゴムが前 ロールに巻き付いて透明な粘弾性流体のバンドゴムとな り，ニップ上に回転するバンクができ，素練りが行われる 領域である。領域 3 では，ロール温度が上昇して $100{ }^{\circ} \mathrm{C} に$ なるとゴムが濁りロールに巻き付かずに袋状に垂れ下がる

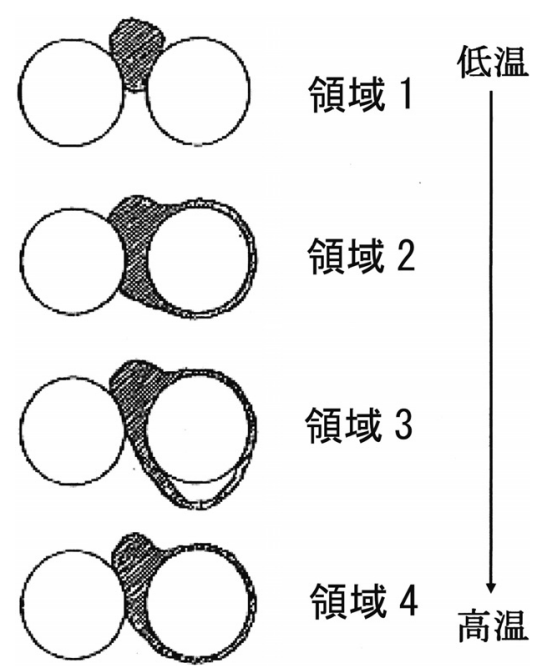

図5 オープンロール温度と練り挙動

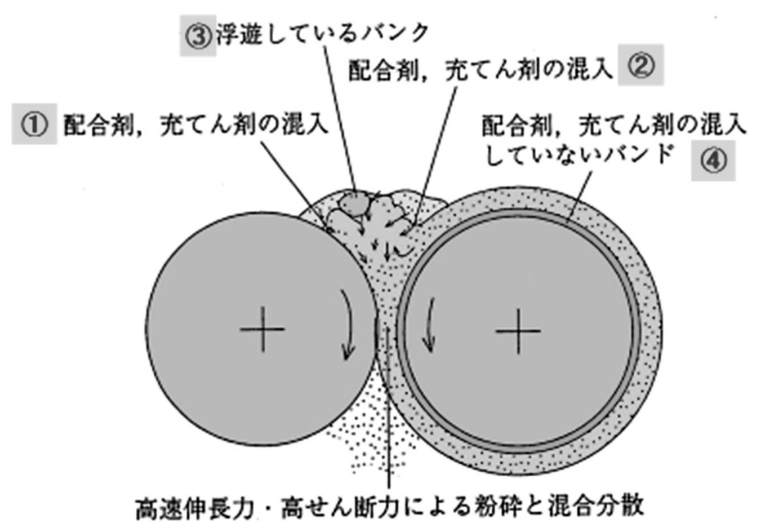

図6 オープンロールの混練りモデル

領域である。領域 4 では，ロール温度がさらに上昇して $121^{\circ} \mathrm{C}$ となり，ゴムは粘性が支配的な透明な液状となり口 ールに張り付いてしまう領域である。これらのゴムのムー ニー粘度（ML-4）は，35-50である。

図 6 は領域 2 に対応した図であるが，本協会発行のテキ スト ${ }^{17)}$ などに混練りのモデルとして掲載されている.

\section{6. バンク温度とゴム物性}

\section{1 素練りにおけるバンク温度とムーニー粘度}

青江 ${ }^{18)}$ は，工業技術員会第4委員会（カーボンブラッ ク）で行ったゴム用カーボンブラックの評価の中で，オー プンロールによるゴム練り条件と物理特性との関係を報告 している.この中で, 各委員所属の組織で使用されるオー プンロールの径が $3.5 ， 6 ， 7.5 ， 8.9 ， 10 ， 12$ インチなど直 径の差ばかりでなくロール面長など諸元が異なるので，天 然ゴム（NR，RSS1）の素練りに押いては，たまり（バン ク）ゴム温度を一定にすることにし，ムーニー粘度を測定 している.

例えば，径 10 インチ×長さ 20 インチの左右無段変速の オープンロールにおいて，前ロールを $18 \mathrm{rpm}$ ，温度 $70 \pm$ 
$1{ }^{\circ} \mathrm{C}$ と，後ロールが $70 \pm 5{ }^{\circ} \mathrm{C}$ になった時に素練りを開始 している. 回転比を $1 ： 1 \sim 1 ： 1.6$ と変え, 素練り開始時 $900 \mathrm{~g}$ ，ロール寄板間隔 $36 \mathrm{~cm}, 1.4 \mathrm{~mm}$ の間隙で 5, 15, 25，40 分間練っている．各練り時間後にムーニー粘度測 定のため，各 $100 \mathrm{~g}$ を採取し，開始時と同時間にてロール 間を通過させるため，寄板間隔を $4 \mathrm{~cm}$ ずつ狭めている. たまりゴムの温度はサーミスターで測定している。

その結果，図7（a），(b) に示すように等速回転時は練 り時間とともにたまりゴム温度 $92{ }^{\circ} \mathrm{C}$ (5分) から $82{ }^{\circ} \mathrm{C}$ （40分）まで，また，ムーニー粘度が63.5（5分）から 32 （5分）で大きく低下しているが，回転比が $1 ： 1.6$ と大き くなった場合でもたまりゴム温度が $98{ }^{\circ} \mathrm{C}$ （5分）から $94{ }^{\circ} \mathrm{C}$ （40 分）まで，また，ムーニー粘度が66.0（5分）か ら 40.0 (40分) とその低下は等速時よりも小さい。また, 図8に示すようにたまりゴム温度をロールを冷却しながら $85 \pm 2{ }^{\circ} \mathrm{C}$ に保って同様の実験をした場合，ロールの回転比 に関係なく，ムーニー粘度は等速時 59.0 (5 分) から 33.5 (40分)，1：1.6 時62.0（5分）から 32.0 (40分）とほとん ど実験誤差と思えるバラツキ範囲で一致している。これら の実験においてバンクの回転や回転するバンクの大きさを ほぼ同じにしていることから，素練りにおいてはバンクの 回転挙動などが重要であることが伺える。

さらに，ロール諸元や回転数が異なる 8 インチと 10 イン チロールを用いて，たまりゴム温度と通過回数（ロール時

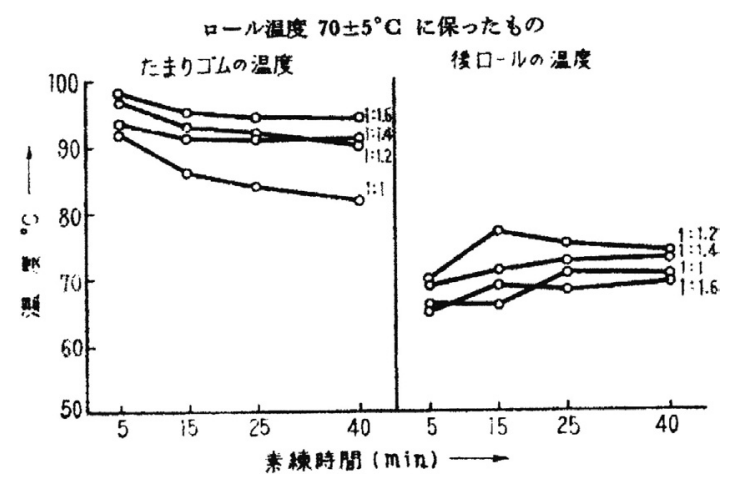

図7（a）たまりゴム温度と後ロール温度

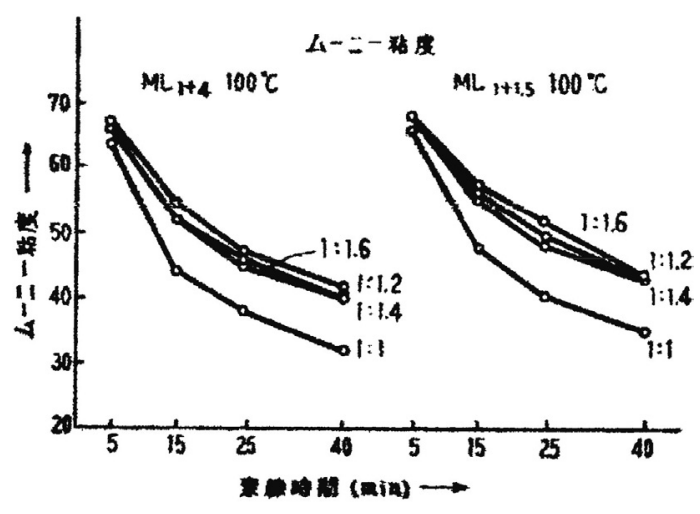

図7(b) ロール回転比とムーニー粘度
間）をコントロールした天然ゴムの素練り実験を行い，図 9 （a）（b）の結果を得ている.10インチ組，8インチ組と 各種の条件を異にするが, 各組の $85^{\circ} \mathrm{C}$ の曲線同志, $65^{\circ} \mathrm{C}$ の曲線同志は測定誤差範囲で一致し, 異径ロール, 異条件 のロールでもたまりゴム温度の一定化を主目的に，他の条 件を考慮すれば同一の素練りが可能であるとしている.

\section{2 混練りにおけるバンク温度とゴム物性}

同委員会は，8名の委員によりカーボンブラックを混合 する混練り実験を $6 ， 8 ， 10$ インチのオープンロールを用 いて行っている. ASTMの混練用ロール基準である径 $6 \pm$ 0.1 in $(150 \sim 155 \mathrm{~cm})$, 寄板間隔 (バンド幅) $10 \sim 11$ in $(23 \sim 28 \mathrm{~cm})$, 前ロールの回転数 $24 \pm 0.5 \mathrm{rpm}$, 回転比 1：1.4をもとに，たまりゴム温度 $80 \pm 5{ }^{\circ} \mathrm{C}$ ，ロール間隙 の通過回数を同じにし，ロール間隙はカーボンブラック混 入開始時 $1.4 \mathrm{~mm}$ を混入中に適当に開き, 混入終了時 （20.5分）までに $1.9 \mathrm{~mm}$ に調節して練り量などを決めて同 一の練り条件で三回にわたり行っている.

配合は，恒粘度NR100.0 部，カーボンブラック（HAF） 50.0 部，亜鉛華 5.0 部，イオウ 2.5 部，ステアリン酸 3.0 部, 促進剂 DM0.6 部である。加硫は， $145{ }^{\circ} \mathrm{C}$ にて 30 分間プレ ス加硫し, 加硫片の物性引張り強度 $\mathrm{T}_{\mathrm{B}}\left[\mathrm{kg} / \mathrm{cm}^{2}\right]$, 伸び $\mathrm{E}_{\mathrm{B}}[\%], 300 \%$ モジュラス $\mathrm{M} 300\left[\mathrm{~kg} / \mathrm{cm}^{2}\right]$, 硬度 $\mathrm{H}_{\mathrm{S}}$ [JIS $]$ を測定している。

その結果，バンク温度は, $76 \sim 89^{\circ} \mathrm{C}$ (4分), $75 \sim 84{ }^{\circ} \mathrm{C}$ （18分）となっているが, 加硫物性の $\mathrm{T}_{\mathrm{B}}$ は $237 \sim 294$ (平 均 258), $\mathrm{E}_{\mathrm{B}}$ は $505 \sim 537$ (平均 517), M300は $119 \sim 139$ (平均 133 ), $\mathrm{H}_{\mathrm{S}}$ は 61 ～68（平均 65）とバラツキがあると 報告している.

これらの報告から，オープンロールによる混練りでもバ ンクの挙動，すなわち，バンク温度やバンクの大きさに関

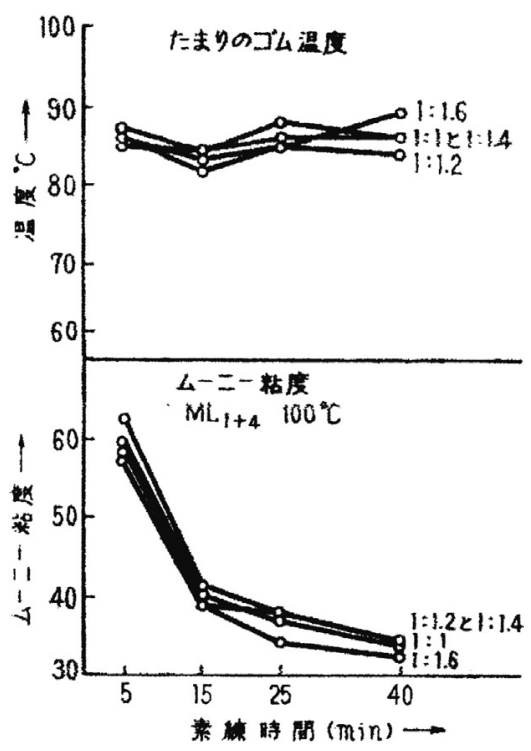

図8 素練り時間を変えた場合のたまりゴム温度とムーニー粘度 

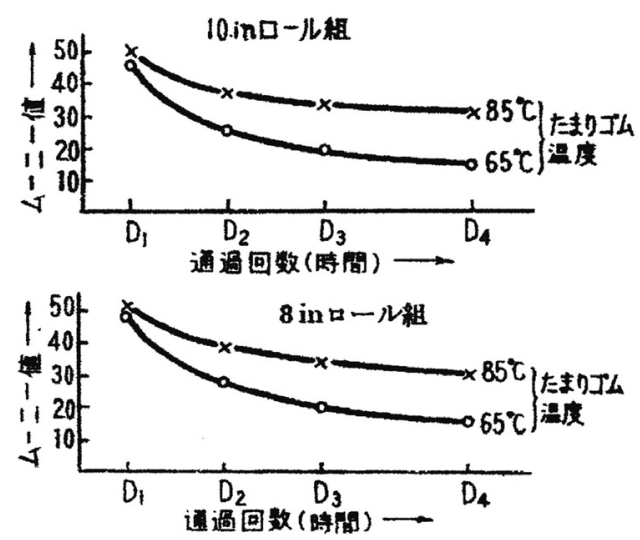

図9（a）たまりゴム温度を一定とした場合の 10 インチロールと 8 イ ンチロールでの練り時間とムーニー粘度の変化

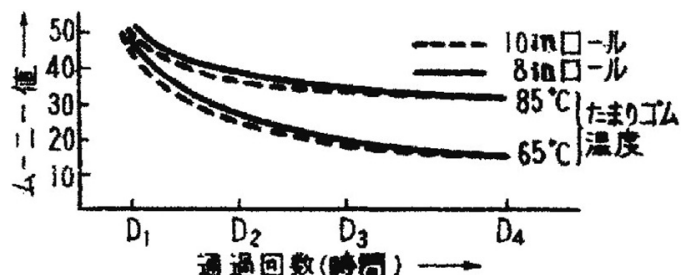

図9(b) 二組のロールでたまりゴム温度を一定とした場合の練り時 間とムーニー粘度変化

わるロール間隙が大きく関わっていることがわかる。

7. お わ り に

オープンロールによるゴムと配合剤の接触は，ただ一か 所ニップ上のバンクで起こり，ゴムがニップを通過すると きに練りが行われるので，ニップ上に形成されるバンクの 挙動は非常に重要である。また，オープンロールにおける 練りの挙動は，ロール温度ではなくゴムの温度と直接関係 するので，ニップ上のバンク温度とニップ直後のゴムの温 度低下が重要となると考える。

\section{References}

1) Fujitani, I.: In “Gomu Kougyou Binran (4th ed.)”, Nippon Gomu Kyoukai Ed. Nippon Gomu Kyoukai, Tokyo, p.1070 (1994)

2 ) Pearson H. C.: In "Rubber Machinery", The India Rubber World, New York, p.59 (1915)

3 ) Young, H. C.: India-Rubber Journal, 78, 621 (1929)

4 ) Young, H. C.: Isiguro, K., Trans.: Gomu, 2, 113 (1929-1931)

5 ) Banks, W. H., Mill, C. C.: Proc. Roy. Soc. (London), A223, 414 (1954)

6 ) Myers, R. R., Miller, J. C.: Trans. Soc. Rheol., 2, 77 (1958)

7 ) Myers, R. R., Hoffman, R. D.: Trans. Soc. Rheol., 5, 317 (1961)

8 ) Chung, G.: "Roll Mill no Sousa Tokusei to Bunsan Tokusei ni Kansuru Kenkyu”, Doctoral Thesis, Kyushu University (1986)

9 ) Toh, M.; Gondoh, T.; Murakami, Y.; Nishimi, H.; Mishima, M.: In "Handbook of Applied Polymer Processing Technology", Marcel Dekker Inc., New York, p.523 (1996)

10) Gondoh T.: 112th Gomuneri Kenkyu Bunkakai Siryou (2014)

11) Toh, M.; Murakami, Y.: Kagaku Kogaku Ronbunshu, 6, 416 (1980)

12) Mori, T.: Gomuseizouhou, Kagakukougyokai, p.71 (1943)

13) Macbeth,C.: "Kautschukmaschinen", In "Handbuch der gesamten Kautschuktechnologie”, (Union Deutsche Verlagsgesellschaft), Berlin, p.155 (1935)

14） Tokita, N., White, J. L.: J. Appl. Polym. Sci., 10, 1011 (1966)

15） Tokita, N., White, J. L.: Rubber Chem. Technol., 40, 1126 (1967)

16) White, J. L.: Rubber Chem. Technol., 50, 163 (1977)

17) Mizumoto, K.: In“Gomu Gijyutsu no Kiso (6th imp.)”, Nippon Gomu Kyoukai Ed., Tokyo, p.146 (1987)

18） Aoe, I.: Nippon Gomu Kyoukaishi, 41, 314 (1968)

\section{日本語表記参考文献}

1 ）藤谷岩男：ゴム工業便覧（改訂4版）, 日本ゴム協会編，日本ゴ 么協会，東京，p.1070（1994）

4 ) 石黒克己訳:護謨，2，113（1929-1931）

8 ）鄭基市：「ロールミルの操作特性と分散性能に関する研究」，九 州大学学位論文 (1986)

10）権藤豊彦：第 112 回ゴム練り研究分科会資料（2014）

11）藤道治，村上泰弘：化学工学論文集，6，417（1980）

12）森鐵之助:ゴム製造法，（社）化学工業協会，東京，p.71（1943）

17）水本清文：ゴム技術の基礎（第6刷）, 日本ゴム協会編，東京， p.146 (1987)

18）青江一郎：日本ゴム協会誌，41，314（1968） 